\title{
Performance, carcass parameters, meat quality and lipid profile from feedlot young bulls fed cottonseed
}

\author{
Desempenho, parâmetros de carcaça, qualidade de carne e perfil lipídico de bovinos \\ em confinamento suplementados com caroço de algodão
}

\author{
ESTEVES, Claudiana ${ }^{1}$; VARASCHIN, Mary Suzan ${ }^{1}$; GARBOSSA, Cesar Augusto \\ Pospissil'; ;ARÇAL, Joanna Oliveira ${ }^{1}$; CARVALHO, Fernanda Paul de ${ }^{1}$; FARIA, \\ Peter Bitencourt ${ }^{1 *}$
}

\author{
${ }^{1}$ Universidade Federal de Lavras, Departamento de Medicina Veterinária, Lavras, Minas Gerais, Brasil. \\ ${ }^{2}$ Universidade Federal Rural da Amazônia, Paragominas, Pará, Brasil. \\ *Endereço para correspondência: peterbfvet@yahoo.com.br
}

\section{SUMMARY}

The objective of this study was to evaluate the performance, carcass, meat quality, fatty acid profile and liver alterations of cattle supplemented with cottonseed feedlot. It used 100 Nelore cattle, being divided into two groups of 50 animals, which received a cottonseed (CS) in grain form by the diet in the proportion of $15 \%$ and the other group was provided with control diet without CS in the feedlot for 88 days. The diets were isoprotein and isoenergetic and concentrate:roughage ratio of 60:40. The animals were slaughter in the end of experimental time and the collection of liver samples for histological analysis. After cooling 24 hours at $\pm 1^{\circ} \mathrm{C}$ were conducted evaluation of carcass and major cuts, final $\mathrm{pH}$ and collected muscle samples longissimus to carry out the physicochemical analyzes (Color, Cooking Loss, Pigments and Shear Force), chemical composition, fatty acid profile and oxidation. The inclusion of CS in the diet provided animals with higher slaughter weight, daily weight gain, Hindquarter, however, the animals showed reduced carcass yield, forequarter weight and Thin flank, without changing the parameters as rib-eye area and backfat thickness. There was an increase of the yellow values $\left(b^{*}\right)$ and moisture with the final $\mathrm{pH}$ reduction. There was no influence of the use of cottonseed in relation to histological parameters evaluated in the liver. The cottonseed in the feeding feedlot cattle promoted improvement in animal performance, despite the reduction of the forequarter weight, with appropriate aspects of meat quality, fatty acid profile and conservation.

Keywords: fatty acids, Gossypium hirsutum, subproduts

\section{RESUMO}

O objetivo com este estudo foi avaliar as características de desempenho, carcaça, qualidade de carne, perfil de ácidos graxos e alterações hepáticas de bovinos suplementados com caroço de algodão (CA) em terminação. Utilizou-se 100 animais da raça Nelore, sendo divido em dois grupos de 50 animais, sendo para o grupo 1 foi incluído $\mathrm{CA}$ na forma de grão inteiro na dieta ( $15 \%$ de inclusão) e para o grupo 2 , foi fornecido uma dieta controle. Os animais permaneceram em confinamento durante 88 dias e as dietas fornecidas foram isoproteícas e isoenergéticas, na proporção de Concentrado:Volumoso de 60:40. Ao final do período experimental, os animais foram encaminhados para abate sendo coletadas amostras de fígado para análise histológica. Após resfriamento de 24 horas a $\pm 1^{\circ} \mathrm{C}$, foram realizadas avaliações de carcaça e de cortes principais, $\mathrm{pH}$ e coleta de amostras do músculo Longissimus para realização das análises físicoquímica, de composição centesimal, perfil de ácidos graxos e índice de oxidação. A inclusão do CA na dieta proporcionou animais com maior peso ao abate, ganho de peso diário, rendimento de dianteiro. Porém, os animais apresentaram reduzidos rendimentos de carcaça, peso de traseiro e costelas, sem alterar os parâmetros como área de olho de lombo e cobertura de gordura subcutânea. Houve aumento dos valores de amarelo $\left(b^{*}\right)$ e umidade, com redução de $\mathrm{pH}$ final com uso do CA. Não houve influência do uso de CA em relação aos parâmetros histológicos avaliados no fígado. A inclusão de $15 \%$ de CA promoveu melhoria no desempenho dos bovinos em confinamento, com redução do peso do traseiro e adequados aspectos de 
qualidade de carne, perfil de ácidos graxos e conservação.

Palavras-chave: ácidos graxos, Gossypium hirsutum, subproduto

\section{INTRODUCTION}

The feedlot is one of the most utilized techniques in the beef production systems in order to warrant the weight gain of the animals in the periods of poorest availability of pastures. After the Ordinance number 290 of the Ministry of Agriculture Livestock and Supply (MAPA) in Brazil, the beef cattle production systems were obliged to seek ingredients like cottonseed to compose the animals' diets instead of meat meal used so this ingredient has been widely used in feedlots as a way to increase the energy and replace part of the forage and corn besides of promote reduction of production costs.

Cottonseed is a textile industry byproduct, being utilized in the animal production as an alternative ingredient which demonstrates both performance and characteristic of the carcasses similar to traditional feeds (ROGERS et al., 2002; CRANSTON et al., 2006) which contributes to the energy and protein content of diet without compromising the fiber content. In this way, it is an economically viable alternative presenting low production cost as compared with corn and soybean.

The finishing phase, cattle on energy-rich diets have better efficiency of weight gain and carcass quality and cottonseed is an excellent alternative to the use in feedlot of ruminants for being a feed with protein of high biological value and energy content, making the formulation of diets of minimum cost. Another advantage would be that the fat contained in the produced meat could have a more unsaturated profile in the form of saturated fat, in view of great part of the energy of that feed being in the form of fat, promoting decreased caloric increment and resulting into better feed conversion (AFERRI et al, 2005; MADRUGA et al., 2008). However, increased amounts of unsaturated fatty acids favor the lipid oxidation process, leading meats and other meat products to present a shorter conservation time and there are suspects that cottonseed alters meat quality.

The objective of this work was to conduct a study about the quality of meat of animals fed cottonseed, seeking to evaluate different aspects related to the carcass characteristics, physicochemical composition and fatty acids composition.

\section{MATERIALS AND METHODS}

This study was approved by the Ethics Committee on Animal Use UFLA with protocol number 040/12. The experiment was conducted in the feedlot of Frialto group, located at $15 \mathrm{~km}$ from the town of Sinop-MT. On hundred (100) male animals of the Nelore breed were used, chosen at random in the group of the animals in the feedlot, with average initial weight of $386.19 \pm 4.48 \mathrm{~kg}$ and slaughtered weighing $527.82 \pm 17.96 \mathrm{~kg}$, aged between 13 and 36 months. Diets were formulated meeting the requirements of $1.5 \mathrm{~kg}$ daily weight gain according to the NRC (1996). The ingredients were furnished in the form of complete feed with isonitrogenous and isocaloric diets (Table 1). The experiment was arranged in a completely randomized design with two treatments and fifty repetitions; each animal is considered an experimental unit. Two treatments were carried out: in Treatment A, 50 animals were given the diet without cottonseed and in Treatment B, 
apparatus operating in the CIEL*a*b* $\left(\mathrm{L}^{*}\right.$ -luminosity, $\mathrm{a}^{*}$ - redness and $\mathrm{b}^{*}$ yellowness) system with a D65 illuminant gauged to the tile white pattern. Readings were done on three cuts of the same muscle and on three different points inside each cut. For the color, still the saturation indices $\left(\mathrm{C}^{*}\right)$ and the tone angle $\left(\mathrm{h}^{*}\right)$ were determined.

For determination of weight loss by cooking (CL), the samples were weighted on a semi-analytical balance, Mettler $\mathrm{M}$ P1210 (Toledo, Brazil), later wrapped in aluminum paper and submitted to cooking on hot plate at $150^{\circ} \mathrm{C}$ till it exceeded $72^{\circ} \mathrm{C}$ in the inside of the sample. For Shear Force (SF) used to Warner Bratzler probe coupled to the Texturometer, model TA XT-2 and the results expressed in kgf.

For the analysis of fatty acids (FA), lipids were extracted according to Folch et al. (1957) being esterified and separated by Hartman \& Lago (1973). The determination of the fatty acid profile was done by gas chromatography using a fused silica capillary column $100 \mathrm{~m}$ in length, $0.25 \mathrm{~mm}$ in diameter and $0.2 \mu \mathrm{m}$ of thickness of the Supelco film (SP-2560, Bellefonte, PA, US). The chromatographic conditions were initial column temperature of $140^{\circ} \mathrm{C} / 5$ minutes; increased $4^{\circ} \mathrm{C} /$ minute up to $240^{\circ} \mathrm{C}$ and kept for 30 minutes, amounting to 60 minutes. The injector temperature was $260^{\circ} \mathrm{C}$. The carrier gas used was helium. The identification and quantification of fatty acids were made according to the Supelco ${ }^{\circledR} 37$ standard (Fame Mix). After the readings obtained, each fatty acid was expressed in percentage (\%) of the total of identified fatty acids, the total of unsaturated, saturated, monounsaturated, polyunsaturated, $\omega 6, \omega 3$ fatty acids and their ratios being calculated. The activity of enzyme $\Delta 9$ desaturase and elongase was estimated according to Malau-Aduli et al. (1998) and Kazala et al. (1999). The indices of atherogenicity and thrombogenicity were computed according to Ulbricht \& Southgate (1991).

For determination of the storage time of the frozen meat, the determination of the oxidation index through TBA technique (thiobarbituric acid) was employed. The determination of the TBARs index was by spectrophotometer and results expressed in malonaldehyde $/ \mathrm{kg}$ of meat. For the determination pigment in the meat were by methods of Ramos \& Gomide (2012) and values in $\mathrm{mg} / \mathrm{g}$ of sample.

Liver samples were fixed in $10 \%$ formalin solution for realization of histological sections. For histological processing, set samples were cut, packaged and processed after the histological slides stained with hematoxylin and eosin. The histological sections of the livers were analyzed using optical microscopy, with any observations classified in scores (HOSE et al., 1996).

The data obtained in the different treatments were submitted to the analysis of variance through the means test (F Test $(\alpha=0.05))$ to GLM of SAS (SAS 9.3 Inst. Inc., Cary, NC) ${ }^{\circledR}$ statistical package.

\section{RESULTS AND DISCUSSION}

The results for evaluation of the performance and carcass parameters are presented in Table 2. The animals supplemented obtained greater weight of DWG and higher final weight. However there were no significant differences among the treatments for the exit weight of the animals, rib-eye area, BFT and carcass weight. Costa et al. (2011) found similar results for the rib-eye area values according to different cottonseed levels in the diet. While for daily weight gain, carcass final weight and fat thickness these authors found a linear decrease effect with increasing levels of cottonseed up to $34.09 \%$. However, Aferri et al. (2005) were working with the inclusion of $21 \%$ of 
cottonseed in the diet of cattle and found similar results to this study for carcass parameters and higher dosages of blood urea. Such effects are related to the reduction of the activities of cellulolytic and methanogenic bacteria there are present in the rumen due to the amount of fatty acids unsaturated in cottonseed (MACHADO NETO et al., 2014), thus providing a greater passage of nitrogen to the bloodstream.

The use of cottonseed to the level of $15 \%$ for cattle indicate that the addition of this component provides an efficient energy supplementation with better performance characteristics and appropriate deposition of fat in the carcass. Despite the difference in ether extract (EE) levels of the diet with use to cottonseed in BFT there were difference observed this work. Ruegger Corte et al. (2015) working with sheep with inclusion level of $20 \%$ of cottonseed also found no influence on the carcass parameters.

Table 2. Performance, carcass parameters, physicochemical parameters and centesimal composition of the meat of cattle in feedlot supplemented with cottonseed

\begin{tabular}{|c|c|c|c|c|}
\hline \multirow{2}{*}{ Parameters } & \multicolumn{2}{|r|}{ Diets } & \multirow{2}{*}{$\mathrm{SEM}^{\mathrm{a}}$} & \multirow{2}{*}{ Value of $\mathrm{P}^{\mathrm{b}}$} \\
\hline & Control & Cottonseed (15\%) & & \\
\hline \multicolumn{5}{|l|}{ Performance } \\
\hline Initial Weight $(\mathrm{kg})$ & 390.67 & 381.71 & 8.44 & 0.7214 \\
\hline Final Weight (kg) & 509.86 & 545.78 & 10.52 & 0.0031 \\
\hline DWG (kg/day) & 1.35 & 1.86 & 0.05 & $<0.0001$ \\
\hline \multicolumn{5}{|l|}{ Carcass } \\
\hline Rib-eye area $\left(\mathrm{cm}^{2}\right)$ & 67.85 & 65.43 & 1.61 & 0.2879 \\
\hline $\mathrm{BFT}(\mathrm{mm})$ & 7.15 & 6.10 & 0.39 & 0.1150 \\
\hline Carcass weight $(\mathrm{kg})$ & 279.82 & 281.43 & 6.05 & 0.2854 \\
\hline HCY (\%) & 54.92 & 51.67 & 0.57 & $<0.0001$ \\
\hline Forequarter $(\mathrm{kg})$ & 115.57 & 105.97 & 2.86 & 0.0062 \\
\hline Forequarter Yield (\%) & 39.61 & 39.09 & 0.20 & 0.0636 \\
\hline Hindquarter $(\mathrm{kg})$ & 141.00 & 135.06 & 2.45 & 0.1247 \\
\hline Hindquarter Yield (\%) & 48.61 & 50.25 & 0.24 & $<0.0001$ \\
\hline Thin flank $(\mathrm{kg})$ & 34.36 & 28.87 & 0.87 & $<0.0001$ \\
\hline Thin flank Yield (\%) & 11.78 & 10.65 & 0.13 & $<0.0001$ \\
\hline \multicolumn{5}{|l|}{ Physicochemical } \\
\hline $\mathrm{pH}_{24 \mathrm{~h}}$ & 5.72 & 5.54 & 0.04 & 0.0013 \\
\hline L* (lightness) & 26.14 & 27.39 & 0.53 & 0.1039 \\
\hline $\mathrm{a}^{*}$ (redness) & 18.45 & 19.19 & 0.62 & 0.3508 \\
\hline b* (yellowness) & 16.81 & 18.03 & 0.41 & 0.0422 \\
\hline $\mathrm{C}^{*}$ (Chroma index) & 25.00 & 26.36 & 0.72 & 0.1654 \\
\hline $\mathrm{h}^{*}$ (Tone angle) & 42.69 & 43.53 & 0.47 & 0.2144 \\
\hline Cooking Loss (\%) & 32.13 & 34.41 & 2.14 & 0.5975 \\
\hline Shear Force (kgf) & 11.06 & 12.49 & 0.49 & 0.0638 \\
\hline \multicolumn{5}{|l|}{ Centesimal composition } \\
\hline Ashes (\%) & 1.23 & 1.22 & 0.04 & 0.1870 \\
\hline Moisture (\%) & 74.89 & 75.53 & 0.13 & 0.0018 \\
\hline Ether extract (\%) & 3.12 & 3.06 & 0.15 & 0.7849 \\
\hline Protein $(\%)$ & 18.39 & 18.12 & 0.23 & 0.4279 \\
\hline Total Pigments (mg/g) & 1.81 & 1.73 & 0.045 & 0.2398 \\
\hline
\end{tabular}


The animals fed cottonseed presented lower weight and Thin flank yield and, there was no statistical difference for the forequarter cut yield for the two treatments. For the hindquarter cut yield, difference with highest mean was found for cottonseed-supplemented animals and reduced values for weight forequarter (Table 2). On the other hand, Oliveira et al. (2013) evaluating different fonts lipid in supplementation of feedlot cattle, verified difference from Thin flank with higher averages for animals supplemented with cottonseed, while for the other cuts (hindquarter and forequarter) was not found differences with control group. Cranston et al. (2006) in including 15.1\% of cottonseed in the diet of beef steers obtained results similar to that of this present study for the Rib-eye area and BFT, however, these authors found no differences for DWG and HCY on the contrary of the results obtained in this work. Costa et al. (2011) with increased addition of cottonseed into the diet of cattle, found reduction of the carcass weight and coverage Backfat thickness.

The final $\mathrm{pH}$ values $(24 \mathrm{~h})$ are within the normal range expected for beef; however, there was significant reduction for meats obtained from the cottonseed-treated group (Table 2). This result may be related to increased nutritional delivery to the muscle and consequently largest reserves of muscle glycogen, favoring the $\mathrm{pH}$ drop in the process of "transformation of the muscle in meat" due to the glycogenolysis effect. Although some authors have not found of influence on the initial $\mathrm{pH}$ and final $\mathrm{pH}$ of the meat of different species with use of cottonseed in the diet of animals (AFERRI et al., 2005; VIEIRA et al., 2010; MACHADO NETO et al., 2104; RUEGGER CORTE et al., 2015).

The results showed to the group treated with cottonseed there was a significant increase in values of $b^{*}$ (yellowness). However, Vieira et al. (2010) observed linear increase in $b *$ values in sheep meat according cottonseed level in the diet, this effect due gossypol which is a polyphenolic pigment rich in carotenoids that are deposited in adipose tissues of the muscle.

For the values of $\mathrm{L}^{*}$ (lightness), $\mathrm{a}^{*}$ (redness), chroma index $\left(\mathrm{C}^{*}\right)$ and tone angle $\left(h^{*}\right)$ there was no alteration; that result being similar in the meat with use of cottonseed by Costa et al. (2013) in cattle and Rugger Corte et al. (2015) in sheep. Vieira et al. (2010) have used cottonseed until the level of $40 \%$ in the diet of sheep found no effect on the values of $a *$ in the meat.

The use of cottonseed in the cattle diet did not change the amount of total pigments (Table 2). The main pigment found in meat is myoglobin is being 80 to $90 \%$ relative to the total and this can be influenced by many factors such as species, breed, age, sex, type of muscle and exercise, as well as factors pre-slaughter (FORREST et al., 1979).

The results of the Cooking Loss and Shear Force analysis showed no difference in relation to the diets. In general, they are not reported effects of the use of cottonseed on these parameters for beef cattle and sheep (AFERRI et al., 2005; VIEIRA et al., 2010; COSTA et al., 2013; RUEGGER CORTE et al., 2015).

No significant alterations occurred in relation to the amount of ether extract, ashes and protein and just come to reduction in the moisture content in the group of animals which were fed cottonseed (Table 2). Similar results with use of cottonseed were found by Madruga et al. (2008) in the meat sheep and Machado Neto et al. (2014) working with cottonseed crushed in beef. Costa et al. (2103) found different results with an increase in moisture values and reduction of ether extract content in beef. In general there is a negative correlation between fat content and moisture, that is, the greater the 
content of ether extract the lower the amount of moisture in meat, despite not being verified in this study this effect.

The fatty acid profile of the meat of bovine animals has not been changed by the use of cottonseed to $15 \%$ inclusion level (Table 3 ) and the total of saturated, monounsaturated and polyunsaturated fatty acids present in the cuts of beef also showed no significant differences among the groups of animals. Machado Neto et al. (2014) supplying diet with cottonseed crushed level of $24 \%$ for cattle Red North breed, found profile modification of fatty acids with decreasing palmitoleic (C16:1), heptadecanoic (C17:1), oleic (C18:1cis9), conjugated linoleic acid (CLA) (C18:2c9t11), levels of unsaturated, unsaturated/saturated and monounsaturated fatty acids; while it increased for the linoleic acid $(\mathrm{C} 18: 2 \mathrm{c} 9 \mathrm{c} 12)$ and octodecanoic (C18:1t10t11t12) and higher proportions of saturated, $\omega 6$ and $\omega 6 / \omega 3$.

Paim et al. (2014) found an increase in fatty acid C15:0; 16:0, C17:0, C17:1, C18:0, saturated total, $\omega 6 / \omega 3$ and decrease

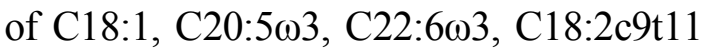

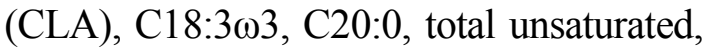
$\omega 3$, unsaturated/saturated for supplying whole cottonseed to sheep until the level of $39 \%$. Profile Changing of fatty acids, was found by Costa et al. (2013) for increasing levels of cottonseed to $34.09 \%$ in the diet of cattle and increased the amount of C13:0, C14:0, C15:0, C17:0 and C18:0 beside a decrease of C14:1, C16:1, C17:1, C18:1cis9 and monounsaturated fatty acids.

In meat of sheep, Madruga et al. (2008) reported similar results in this study for most of the identified fatty acids and of saturated levels, monounsaturated and polyunsaturated, except for myristic (C14:0), palmitic (C16:0) and linolenic $(\mathrm{C} 18: 3 \omega 3)$ that were influenced by cottonseed levels in the diet. Despite the cottonseed is composed of large amounts of unsaturated fatty acids (mono and polyunsaturated), mainly $\mathrm{C} 18: 2 \omega 6$ and C18:1 cis (MACHADO NETO et al., 2014), in the rumen they are hydrolyzed and polyunsaturated acids are rapidly hydrogenated by bacteria, resulting into the production of saturated fatty acids. Thus, the supply of smaller amounts and in the form of whole cottonseed in the diet showed not be enough to promote change in the fatty acid profile of beef cattle feedlot.

There was no effect of the use of cottonseed on the activity $\Delta 9$-desaturase enzymes $\mathrm{C} 16$ and $\mathrm{C} 18$; Elongase ${ }^{\mathrm{C} 16-\mathrm{C} 18}$ and Thioesterase $^{\mathrm{C16-14}}$ (Table 3). The desaturase acts on the structure and introduction of double bonds in the $\Delta^{5}$ position, $\Delta^{6}$ and $\Delta^{9}$, and enzymes $\Delta^{5}$ and $\Delta^{6}$ act in the desaturation of polyunsaturated fatty acids, while the $\Delta^{9}$ desaturase acts in the synthesis of monounsaturated fatty acids and elongases act adding two carbon atoms to the chain (PERINI et al., 2010). Machado Neto et al. (2014) found lower rates of activity for $\Delta^{9}$-desaturase $\mathrm{C} 16$ and C18 in the meat of cattle feed with cottonseed and associated this effect due sterculic acid action by inhibiting the activity of these enzymes.

According to Ulbritch \& Southgate (1991), the indices of atherogenicity and thrombogenicity are related to the amounts of saturated, polyunsaturated and $\omega 6$ fatty acids present in feeds and therefore, they are an indicator of health related to cardiovascular disease risk. Thus, the lower these rates in a particular feed are the better for the consumer's health. However, no significant differences were found among the treatments for such indices (Table 3). Similar results were also observed by Machado Neto et al. (2014) for beef cattle fed cottonseed compared to other sources of oilseed. 
Rev. Bras. Saúde Prod. Anim., Salvador, v.18, n.2, p.347-358 abr./jun., 2017

Table 3. Lipid profile of the meat of cattle in feedlot supplemented with cottonseed

\begin{tabular}{|c|c|c|c|c|}
\hline \multirow{2}{*}{ Variable } & \multicolumn{2}{|c|}{ Diets } & \multirow{2}{*}{$\mathrm{SEM}^{\mathrm{a}}$} & \multirow{2}{*}{ Value of $\mathrm{P}^{\mathrm{b}}$} \\
\hline & Control & Cottonseed (15\%) & & \\
\hline C10:0 & 0.076 & 0.079 & 0.963 & 0.4376 \\
\hline $\mathrm{C} 12: 0$ & 0.095 & 0.101 & 0.005 & 0.3094 \\
\hline C13:0 & 0.007 & 0.006 & 0.001 & 0.8335 \\
\hline C14:0 & 2.425 & 2.455 & 0.068 & 0.7571 \\
\hline C14:1 & 0.429 & 0.425 & 0.020 & 0.8906 \\
\hline $\mathrm{C} 15: 0$ & 0.341 & 0.339 & 0.012 & 0.8473 \\
\hline C16:0 & 24.374 & 24.502 & 0.131 & 0.5257 \\
\hline C16:1 & 3.081 & 2.977 & 0.049 & 0.1090 \\
\hline $\mathrm{C} 17: 0$ & 0.898 & 0.893 & 0.021 & 0.8497 \\
\hline $\mathrm{C} 17: 1$ & 0.664 & 0.663 & 0.018 & 0.9955 \\
\hline C18:0 & 14.907 & 15.434 & 0.412 & 0.3654 \\
\hline $\mathrm{C} 18: 1 \omega 9 \mathrm{t}$ & 1.442 & 1.627 & 0.117 & 0.1201 \\
\hline $\mathrm{C} 18: 1 \omega 9 \mathrm{c}$ & 39.624 & 39.040 & 0.605 & 0.5534 \\
\hline $\mathrm{C} 18: 2 \omega 6 \mathrm{t}$ & 0.110 & 0.118 & 0.006 & 0.2025 \\
\hline $\mathrm{C} 18: 2 \omega 6 \mathrm{c}$ & 9.327 & 9.090 & 0.896 & 0.7699 \\
\hline $\mathrm{C} 20: 0$ & 0.152 & 0.143 & 0.005 & 0.1134 \\
\hline $\mathrm{C} 18: 3 \omega 6$ & 0.032 & 0.027 & 0.004 & 0.2428 \\
\hline C20:1 & 0.300 & 0.276 & 0.022 & 0.3285 \\
\hline $\mathrm{C} 18: 3 \omega 3$ & 0.511 & 0.488 & 0.027 & 0.4193 \\
\hline $\mathrm{C} 20: 2$ & 0.177 & 0.152 & 0.020 & 0.5063 \\
\hline $\mathrm{C} 22: 0$ & 0.098 & 0.106 & 0.010 & 0.4788 \\
\hline $\mathrm{C} 20: 3 \omega 6$ & 0.145 & 0.164 & 0.013 & 0.1318 \\
\hline $\mathrm{C} 22: 1 \omega 9$ & 0.024 & 0.052 & 0.019 & 0.4489 \\
\hline $\mathrm{C} 20: 4 \omega 6$ & 0.571 & 0.638 & 0.058 & 0.3956 \\
\hline C23:0 & 0.024 & 0.023 & 0.008 & 0.4830 \\
\hline $\mathrm{C} 24: 0$ & 0.020 & 0.025 & 0.008 & 0.7723 \\
\hline $\mathrm{C} 20: 5 \omega 3$ & 0.131 & 0.141 & 0.018 & 0.4702 \\
\hline${ }^{\mathrm{c}} \mathrm{SFA}$ & 43.401 & 44.086 & 0.787 & 0.3865 \\
\hline${ }^{\mathrm{d}}$ MUFA & 45.567 & 45.066 & 0.673 & 0.8188 \\
\hline${ }^{\mathrm{e}} \mathrm{PUFA}$ & 11.010 & 10.822 & 0.942 & 0.8397 \\
\hline${ }^{\mathrm{f}} \Sigma \omega 3$ & 0.644 & 0.631 & 0.037 & 0.7342 \\
\hline${ }^{\mathrm{g}} \sum \omega 6$ & 10.189 & 10.039 & 0.920 & 0.8658 \\
\hline${ }^{\mathrm{h}} \Sigma \omega 6 / \omega 3$ & 16.071 & 16.446 & 1.613 & 0.7643 \\
\hline${ }^{\mathrm{i}} \mathrm{PUFA} / \mathrm{SFA}$ & 0.261 & 0.253 & 0.026 & 0.8060 \\
\hline${ }^{\mathrm{j}} \Sigma \omega 3 / \omega 6$ & 0.069 & 0.068 & 0.004 & 0.7368 \\
\hline${ }^{\mathrm{k}} \Delta 9$-desaturase $\mathrm{C}^{\mathrm{C} 16}$ & 10.833 & 10.833 & 0.231 & 0.1353 \\
\hline${ }^{\mathrm{I}} \Delta 9$-desaturase $\mathrm{C}^{\mathrm{C} 18}$ & 72.761 & 71.724 & 0.877 & 0.2403 \\
\hline${ }^{\mathrm{m}}$ Elongase $^{\mathrm{C} 16-\mathrm{C} 18}$ & 66.455 & 66.416 & 0.347 & 0.9837 \\
\hline${ }^{\mathrm{n}}$ Thioesterase ${ }^{\mathrm{C} 16-14}$ & 90.986 & 90.950 & 0.288 & 0.9016 \\
\hline${ }^{\circ}$ Atherogenicity & 0.627 & 0.626 & 0.010 & 0.9121 \\
\hline${ }^{\mathrm{p}}$ Thrombogenicity & 1.407 & 1.455 & 0.048 & 0.4371 \\
\hline
\end{tabular}

${ }^{\mathrm{a}} \mathrm{SEM}=$ standard error of the mean; ${ }^{\mathrm{b}} \mathrm{F}$ test $(\alpha=0.05)$; ${ }^{\mathrm{c}} \mathrm{Sum}$ of SFA $(\mathrm{C} 10: 0+\mathrm{C} 12: 0+\mathrm{C} 13: 0+\mathrm{C} 14: 0+$ $\mathrm{C} 15: 0+\mathrm{C} 16: 0+\mathrm{C} 17: 0+\mathrm{C} 18: 0+\mathrm{C} 20: 0+\mathrm{C} 22: 0) ;{ }^{\mathrm{d}} \mathrm{Sum}$ of MUFA $(\mathrm{C} 14: 1+\mathrm{C} 16: 1+\mathrm{C} 17: 1+\mathrm{C} 18: 1 \omega 9 \mathrm{t}$ $+\mathrm{C} 18: 1 \omega 9 \mathrm{c}+\mathrm{C} 20: 1+\mathrm{C} 22: 1 \omega 9) ;{ }^{\mathrm{e}} \mathrm{Sum}$ of PUFA $(\mathrm{C} 18: 2 \omega 6 \mathrm{t}+\mathrm{C} 18: 2 \omega 6 \mathrm{c}+\mathrm{C} 18: 3 \omega 6+\mathrm{C} 18: 3 \omega 3+$ $\mathrm{C} 20: 4 \omega 6+\mathrm{C} 20: 3 \omega 6+\mathrm{C} 20: 5 \omega 3) ;{ }^{\mathrm{f}} \mathrm{S} u m$ of PUFA of the $\omega 6$ series $(\mathrm{C} 18: 2 \omega-6 \mathrm{t}+\mathrm{C} 18: 2 \omega-6 \mathrm{c}+\mathrm{C} 18: 3 \omega-6+$ $\mathrm{C} 20: 4 \omega-6+\mathrm{C} 20: 3 \omega 6) ;{ }^{g} \mathrm{Sum}$ of PUFA of the $\omega 3$ series $(\mathrm{C} 18: 3 \omega-3+\mathrm{C} 20: 5 \omega 3) ;{ }^{\mathrm{h}}$ Ratio sum $\omega 6 / \omega 3$ $(\Sigma \omega 6 / \Sigma \omega 3) ;{ }^{\mathrm{i}}$ Ratio sum PUFA/SFA; ${ }^{\mathrm{j}}$ Ratio sum $\omega 3 / \omega 6(\Sigma \omega 3 / \Sigma \omega 6) ;{ }^{\mathrm{k}}$ Index of C16 desaturase activity $=100$ $[(\mathrm{C} 16: 1) /(\mathrm{C} 16: 1+\mathrm{C} 16: 0)] ;{ }^{1}$ Index of $\mathrm{C} 18$ desaturase activity $=100[(\mathrm{C} 18: 1 \omega 9 \mathrm{c}) /(\mathrm{C} 18: 1 \omega 9 \mathrm{c}+\mathrm{C} 18: 0)]$; ${ }^{\mathrm{m}}$ Index of $\mathrm{C} 16$ to $\mathrm{C} 18$ elongase activity $=100[(\mathrm{C} 18: 0+\mathrm{C} 18: 1 \omega 9 \mathrm{c}) /(\mathrm{C} 16: 0+\mathrm{C} 16: 1+\mathrm{C} 18: 0+$ $\mathrm{C} 18: 1 \omega 9 \mathrm{c})] ;$ " ${ }^{\mathrm{I}}$ Index of $\mathrm{C} 16$ to $\mathrm{C} 14$ thioesterase activity $=100[(\mathrm{C} 16: 0) /(\mathrm{C} 16: 0+\mathrm{C} 14: 0)] ;{ }^{\circ}$ Index of atherogenicity $=[4(\mathrm{C} 14: 0)+\mathrm{C} 16: 0] /($ Sum SFA + Sum PUFA $) ;{ }^{\mathrm{p}}$ Index of thrombogenicity $=(\mathrm{C} 14: 0+$ $\mathrm{C} 16: 0+\mathrm{C} 18: 0) /[(0.5 \mathrm{x}$ MUFA $)+(0.5 \times \Sigma \omega 6)+(3 \times \Sigma \omega 3)+(\Sigma \omega 3 / \omega 6)]$. 
In the Table 4 is presented the results of the analysis of the oxidation indices (TBARs) in cattle which were given or not cottonseed $(15 \%$ in the diet). In the study no significant alteration in the values of oxidation owing to the treatments was observed. This behavior was observed due to the similar results for fatty acids profile and lipid levels in muscle, indicating that the use of level cottonseed to $15 \%$ in the cattle diet does not interfere with the period of shelf life of the beef. A similar result was reported by Costa et al. (2013) with the use of up to $34.09 \%$ of cottonseed in cattle diet. Machado Neto et al. (2014) evaluated the oxidation of Longissimus dorsi muscle of cattle fed with the use of different sources of oilseeds that have been stored for 42 days at $2^{\circ} \mathrm{C}$ found reduction in the concentration of malonaldehyde for this group compared of soy. According to Rhee et al. (2001), the presence of flavonoids and phenolic compounds that are found in cotton seeds that have antioxidative properties and may contribute to lower oxidation rate and contribute to increase shelf life of meat products. However, relative to the storage time an increase in the TBAR index was found, independent of the treatments utilized.

Table 4.Evaluation of the oxidative stability beef with use to cottonseed and storage time in feedlot

\begin{tabular}{|c|c|c|c|c|c|c|}
\hline \multirow{2}{*}{ Time } & \multicolumn{2}{|r|}{ Diets } & \multicolumn{3}{|c|}{ Value of $\mathrm{P}^{\mathrm{a}}$} & \multirow[b]{2}{*}{$\mathrm{SEM}^{\mathrm{b}}$} \\
\hline & Control & Cottonseed (15\%) & Time (T) & Diets (D) & $T \times D$ & \\
\hline 15 days & 0.071 & 0.082 & \multirow{3}{*}{0.001} & \multirow{3}{*}{0.774} & \multirow{3}{*}{0.838} & \multirow{3}{*}{0.015} \\
\hline 8 months & 0.211 & 0.213 & & & & \\
\hline Mean & 0.141 & 0.147 & & & & \\
\hline
\end{tabular}

Evaluation of the histological structure of the liver feedlot cattle showed no influence of treatment using the cotton seed (Table 5). According to Zeng et al. (2014) the liver is the first organ to be affected by the level of this gossypol in the diet depending on the level of inclusion of whole cottonseed can be found included fatty degeneration lesions, cell necrosis and cellular infiltration and injuries are related to damage to the mitochondria of hepatocytes and may related to providing for long periods or cottonseed high concentrations in the diet. Girginov et al. (2008) reported similar results to this study with the use of cottonseed in the daily amount of $3.5 \mathrm{~kg}$ per cattle during a period of five months, where were the hepatic circulatory changes, inflammations, necrosis, and connective tissue growths. However the occurrence of these changes with aggregation of foamy macrophages in the liver parenchyma is also found in cattle fed using Brachiaria spp. (FACCIN et al., 2015).

In general, the supply of cottonseed levels in feeding cattle by $15 \%$ not are associated with metabolic abnormalities that indicate injury hepatic and can cause harm the organ and performance of animals (MENA et al., 2001; BROWN et al., 2003) and these changes were not sufficient to promote hepatic fibrosis could bring about any condemnation of the organ. 
Rev. Bras. Saúde Prod. Anim., Salvador, v.18, n.2, p.347-358 abr./jun., 2017

Table 5. Alterations in the beef liver with the use of cottonseed in feedlot

\begin{tabular}{lrrrc}
\hline Alterations & Control & Cottonseed & SEM $^{\mathrm{a}}$ & ${\text { Value of } \mathrm{P}^{\mathrm{b}}}^{\text {No }}$ \\
\hline No $(\%)$ & 50.00 & 61.70 & - & - \\
Yes (\%) & 50.00 & 38.30 & - & - \\
\hline Foamy macrophages & 57.69 & 22.22 & - & - \\
Paratyphoid nodules & 23.08 & 50.00 & - & - \\
Multiple alterations & 19.23 & 27.77 & - & - \\
\hline Score: & & & & \\
\hline Vacuolization $^{\mathrm{c}}$ & 1.71 & 1.91 & 0.076 & 0.0635 \\
Inflammation $^{\mathrm{d}}$ & 0.79 & 0.81 & 0.076 & 0.8440 \\
\hline
\end{tabular}

${ }^{\mathrm{a}} \mathrm{F}$ Test $(\alpha=0.05)$; ${ }^{\mathrm{b}} \mathrm{SEM}=$ standard error of the mean; ${ }^{\mathrm{c} S c o r e}$ - Discrete (1): slightly vacuole, more in the area and center-lobular; moderate (2): Center area lobular to the average zonal with vacuoles in the cytoplasm; accentuated (3): covers the lobular area, zonal and liver portal area average; ${ }^{\mathrm{d}}$ Score - slight alteration (1) up to 10 cells; moderate alteration (2): 10 to 20 cells; severe alteration (3): above 20 cells (always looking at the liver portal area).

Use of cottonseed presented a good alternative to be ascribed to the diet of cattle at finishing, for it provided improvement of the performance of the animals, these ones being slaughtered with greater weight and hindquarter yield, where the main cuts situated may be related to higher energy density.

The addition of $15 \%$ of cottonseed increase ether extract of diet in the feeding of cattle in feedlot resulted into meats with greater values of yellow and lower of $\mathrm{pH}$, which favors a longer conservation time and does not alter the lipid oxidation rate of meat.

\section{ACKNOWLEDGEMENTS}

The authors thank to FAPEMIG (Foundation of Support to Research of the State of Minas Gerais), which promotes activities of support to scientific and research, enabling the doing of the study by means of the supply of the financial support; Prodap and Frialto group.

\section{REFERENCES}

AFERRI, G.; LEME, P.R.; SILVA, S.L.; PUTRINO, S.M.; PEREIRA, A.S.C. Desempenho e Características de Carcaça de Novilhos Alimentados com Dietas Contendo Diferentes Fontes de Lipídios.

Revista Brasileira de Zootecnia, v.34, p.1651-1658, 2005.

BOLEMAN, S.J.; BOLEMAN, S.L.; MILLER, R. K.; TAYLOR, J.F.; CROSS, H.R.; WHEELER, T.L.; KOOHMARAIE, M.; SHACKELFORD, S.D.; MILLER, M.F. JOHNSON, D.D.; SAVEL, J.W. Consumer evaluation of beef of known categories of tenderness. Journal of Animal Science, v.75, p.1521-1524, 1997.

BROWN, M.S.; MONTGOMERY, T.H.; BIGGS, T.J. Effect of Dietary Cottonseed Meal Concentration on Feedlot Performance and Carcass Characteristics of Cull Beef Cows. The Professional Animal Scientist, v.19, p.350-356, 2003. 
COSTA, D.P.B.; ROÇA, R.O.; COSTA, Q.P.B.; LANNA, D.P.D.; LIMA, E.S.;

BARROS, W.M. Meat characteristics of Nellore steers fed whole cottonseed.

Revista Brasileira de Zootecnia, v.42, p.183-192, 2013.

COSTA, Q.P.B.; WECHSLER, F.S.; COSTA, D.P.B.; POLIZEL NETO, A.; ROÇA, R.O.; BRITO, T.P. Desempenho e características da carcaça de bovinos alimentados com dietas com caroço de algodão. Arquivo Brasileiro de Medicina Veterinária e Zootecnia, v.63, p.729-735, 2011.

CRANSTON, J.J.; RIVERA, J.D.; GALYEAN, M.L.; BRASHEARS, M.M.; BROOKS, J.C.; MARKHAM, C.E.; MCBETH, L.J.; KREHBIEL, C.R. Effects of feeding whole cottonseed and cottonseed products on performance and carcass characteristics of finishing beef cattle. Journal of Animal Science, v.84, p.2186-2199, 2006.

FACCIN, T.C.; BRUMATTI, R.C.; LIMA, S.C.; MADUREIRA, R.C.; FERNANDES, C.E.S.; KOMMERS, G.D.; LEMOS, R.A.A. Perdas econômicas pela condenação em matadouro frigorífico de fígados de bovino por fibrose causada por ingestão de Braquiaria spp. Pesquisa Veterinária Brasileira, v.35, n.6, p.547-551, 2015.

FOLCH, J.; LEES, M.; STANLEY, S.A. A simple method for isolation and purification of total lipids from animal tissues. Journal of Biological Chemistry, v.226, p.479-503, 1957.

FORREST, J.C.; ABERLE, E.D.; HEDRICK, H.B.; JUDGE, M.D., MERKEL, R.A. Fundamentos de ciência de la carne. Zaragoza: Acribia, 1979. 363p.
GIRGINOV, D.; ANGELOV, A.; TODOROV, N.; TASHEV, T.; MITEV, J. Histopathological alterations in the liver of cows, fed diets supplemented with cottonseed, sunflower seeds and soybean. Trakia Journal of Sciences, v.6, p.37-42, 2008.

HARTMAN, L.; LAGO, R.C.A. Rapid preparation to fatty acids methyl esters. Laboratory \& Practice, n.22, p.475-476, 1973.

HOSE, J.E., McGURK, M.D., MARTY, G.D.; HINTON, D.E.; BROWN, E.D.; BACKER, T.T. Sublethal effects of the Exxon Valdez oil spill on herring embryos and larvae: morphological, cytogenetic, and histopathological assessments, 1989 1991. Canadian Journal of Fish and Aquatic Science, v.53, p.2355-2365, 1996.

KAZALA, E.C.; LOZEMAN, F.J.; MIR, P.S.; LAROCHE, A.; BAILEY, D.R.; WESELAKE, R.J. Relationship of fatty acid composition to intramuscular fat content in beef from crossbred wagyu cattle. Journal of Animal Science, v.77, p.1717-1725, 1999.

MACHADO NETO, O.R.; CHIZZOTTI, M.L.; RAMOS, E.M.; OLIVEIRA, D.M.; LANNA, D.P.; RIBEIRO, J.S.; LOPES, L.S.; DESCALZO, A.M.; AMORIM, T.R.; LADEIRA, M.M. Fatty acid profile and meat quality of young bulls fed ground soybean or ground cottonseed and vitamin E. Animal, v.9, p.362-372, 2014.

MADRUGA, M.S.; VIEIRA, T.R.L.; CUNHA, M.G.G.; PEREIRA FILHO, J.M.; QUEIROGA, R.C.R.E.; SOUSA, W.H. Efeito de dietas com níveis crescentes de caroço de algodão integral sobre a composição química e o perfil de ácidos graxos da carne de cordeiros Santa Inês. Revista Brasileira de Zootecnia, v.37, p.1496-1502, 2008. 
MALAU-ADULI, A.E.O.; SIEBERT, B.D.; BOTTEMA, C.D.K.;

PITCHFORD, W.S. A comparison of the fatty acid composition of triacylglycerols in adipose tissue from Limousin and Jersey cattle. Australian Journal of Agricultural Research, v.48, p.715-722, 1997.

MENA, H; SANTOS, J.E.P.; HUBER, J.T.; SIMAS, J.M.; TARAZON, M.; CALHOUN, M.C. The effects of feeding varying amounts of gossypol from whole cottonseed and cottonseed meal in lactating dairy cows. Journal of Dairy Science, v.84, p.2231-2239, 2001.

\section{NATIONAL RESEARCH COUNCIL-} NRC. Nutrient requirements of beef cattle. 7.ed. rev. Washington: National Academic Press, 1996. p.54-69.

OLIVEIRA, D.M.; LADEIRA, M.M.; CHIZZOTTI, M.L.; BASSI, M.S.; MACHADO NETO, O.R.; BUSATO, K.C. Carcass characteristics of zebu steers receiving different oleaginous grains. Acta Scientiarum. Animal Sciences, v.35, p.301-306, 2013.

PAIM, T.P.; VIANA, P.; BRANDÃO, E.; AMADOR, S.; BARBOSA, T.; CARDOSO, C.; DANTAS, A.M.M.; SOUZA, J.R.; MACMANUS, C.; ABDALLA, A,.L.; LOUVANDINI, H. Carcass traits and fatty acid profile of meat from lambs fed different cottonseed by-products. Small Ruminant Research, v.116, p.71-77, 2014.

PERINI, J.A.L.; STEVANATO, F.B.; SARGI, S.C.; VISENTAINER, J.E.L; DALALIO, M.M.O.; MATSHUSHITA, M.; SOUZA, N.E.; VISENTAINER, J.V. Ácidos graxos poli-insaturados n-3 e n-6: metabolismo em mamíferos e resposta imune. Revista de Nutrição, v.23, p.1075-1086, 2010.
RAMOS, E.M.; GOMIDE, L.A. de M. Avaliação da qualidade de carnes: fundamentos e metodologias. 2.ed. reimp. Viçosa, MG: UFV, 2012. 599p.

RHEE, K.S.; ZIPRIN, Y.A.; CALHOUN, M.C. Antioxidative effects of cottonseed meals as evaluated in cooked meat. Meat Science, v.58, p.117-123, 2001.

ROGERS, G.M.; POORE, M.H.; PASCHAL, J.C. Feeding cotton products to cattle. Veterinary Clinics of North America: Food Animal Practice, v.18, p.267-94, 2002.

RUEGGER CORTE, R.; AFERRI, G.; PEREIRA, A.S.C.; SILVA, S.L.; PESCI, D.M.C.; LEME, P.R. Performance, Carcass Traits and Meat Quality of Crossbred Lambs Fed Whole Cottonseed Levels. Italian Journal of Animal Science, v.14, p.723-726, 2015.

ULBRITCH, T.L.V.; SOUTHGATE, D.A.T. Coronary heart disease:seven dietary factors. Lancet, v.338, p.985-992, 1991.

VIEIRA, T.R.L.; CUNHA, M.G.G.; GARRUTTI, D.S.; DUARTE, T.F.; FELEX, S.S.S.; PEREIRA FILHO, J.M.; MADRUGA, M.S. Propriedades físicas e sensoriais da carne de cordeiros Santa Inês terminados em dietas com diferentes níveis de caroço de algodão integral (Gossypium hirsutum). Ciência e Tecnologia de Alimentos, v.30, p.372-377, 2010.

ZENG, Q.F.;YANG, G.L.; LIU, G.N.; WANG, J.P.; BAI, S.P.; DING, X.M.; LUO, Y.H.; ZHANG, K.Y. Effects of dietary gossypol concentration on growth performance, blood profiles, and hepatic histopathology in meat ducks. Poultry Science, v. 93, p.1-10, 2014.

Data de recebimento: 17/08/2016 Data de aprovação: 16/06/2017 
Errata

No artigo "Performance, carcass parameters, meat quality and lipid profile from feedlot young bulls fed cottonseed", com número de DOI: 10.1590/s151999402017000200013, publicado no periódico Revista Brasileira de Saúde e Produção Animal, v.18, n.2, p.347-358 abr./jun., 2017, na página 347:

Onde se lia:

"FARIA, Peter Bitencourt ${ }^{1 *}$; TEIXEIRA, Jacyara Thais ${ }^{2}$; VARASCHIN, Mary Suzan"; GARBOSSA, Cesar Augusto Pospissi1 ${ }^{3, "}$.

Leia-se:

"ESTEVES, Claudiana'; VARASCHIN, Mary Suzan"; GARBOSSA, Cesar Augusto Pospissil' $^{2}$; MARÇAL, Joanna Oliveira ${ }^{1}$; CARVALHO, Fernanda Paul de ${ }^{1}$; FARIA, Peter Bitencourt ${ }^{1 *}$," 